\title{
Community-Based Distribution in Tanzania: Costs and Impacts of Alternative Strategies To Improve Worker Performance
}

By Barbara Janowitz, Jane Chege, Andrew Thompson, Naomi Rutenberg and Rick Homan

\begin{abstract}
Context: Donor funds may be inadequate to support the growing demand for services provided by community-based distribution (CBD) programs. One solution may be to reduce the remuneration of CBD agents, but this approach may lower their productivity. Programs also need to consider reducing other costs, including those for supervision and training.
\end{abstract}

Methods: The cost per agent visit_-including costs associated with payments to agents and to supervisors and the costs of training — was calculated for three CBD programs in Tanzania. The output measure was visits in which contraceptives were provided or referrals made for family planning services. Simulations were used to examine the impact of changes in agent remuneration on costs per visit, assuming different levels of spending on training and supervision.

Results: The program that paid agents the highest annual compensation (US\$398) also had the highest costs per agent (\$701), but it had the highest number of visits per agent (425). The program that had the lowest annual payments per agent (\$33) also had high costs per agent (\$558), because its other costs were high and its agents produced few visits (105). The simulations showed that an increase in the amount spent on agent remuneration reduces costs per visit, because the number of agent visits increases, thereby spreading out supervision and training costs over a larger number of visits.

Conclusions: The challenge for $C B D$ programs seeking to reduce their costs is to determine which cost components to decrease so as to minimize any reduction in visits. For example, programs that spend little on compensation might improve their performance by spending more on compensation but less on training or supervision.

International Family Planning Perspectives, 2000, 26(4):158-160 \& 193-195

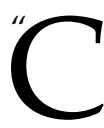

ommunity-based distribution" (CBD) of nonclinical family planning services refers to programs that use community organizations, structures and institutions to promote the use of safe and simple contraceptive technologies. In Africa, community-based family planning programs typically focus on the provision of oral contraceptives, foaming tablets and condoms. A CBD program may also include prevention strategies for AIDS and other sexually transmitted diseases, or the provision of other health services. CBD workers may operate out of health posts or depots, or may visit women in their homes. They may be volunteers, or may be paid a sales commission or a salary. CBD reduces the costs of contraception, thereby extending use among clients who seek contraceptives but will not use services that are confined to clinical settings. ${ }^{1}$

CBD programs originated in Asia in the 1960s and spread throughout Asia and Latin America in the 1970s and 1980s. They were introduced in Sub-Saharan Africa during the 1980s and 1990s; by 1996, almost half of the population of SubSaharan Africa lived in countries exhibiting some CBD effort. As a result of poli- cies of the U.S. Agency for International Development (USAID), the United Nations Population Fund and German Technical Cooperation (GTZ), CBD has been made "a routine part of external assistance to family planning programs" and its proliferation has been fostered. ${ }^{2}$

Because donors' levels of funding for family planning are stagnant or decreasing, financial resources to support CBD programs could prove inadequate. One response to inadequate funding is to shift the payment burden to the client by charging (or charging more) for services; strategies for reducing the costs of CBD programs, including compensation paid to field-workers and their supervisors and the cost of training, also merit attention.

One way to reduce costs is to lower or eliminate salaries or other payments made to CBD agents. However, this strategy may discourage agents from visiting households. If lower compensation leads to lower productivity, then the resources used to spread over a smaller output. Thus, in making decisions about how much to pay CBD agents, programs also need to consider what they spend on training and supervision. Furthermore, changes in compensasupport training and supervision will be tion not only directly affect the program's output, but also indirectly affect the productivity of other strategies to improve agent performance. Spending large amounts on training or supervision limits the availability of funds to remunerate agents, and may not greatly affect performance. Without adequate compensation, agents may perform poorly even if they are trained and supervised well.

In this article, we examine the impact of strategies to improve worker performance in Tanzania, where agents' compensation and other costs differ widely among CBD programs. The impetus for this research came from the USAID mission in Tanzania. Officials there were concerned that costs at a USAID-supported program were too high because agents received a fulltime salary, and they wanted to know if productivity in this program was high enough to justify the large amounts spent on remuneration. In the course of that research, it became apparent that an examination of remuneration policies also had to take into consideration other strategies for improving worker performance.

CBD programs in Tanzania date back to 1988, when the International Planned Parenthood Federation launched a program through the Family Planning Association of Tanzania, which is known by the acronym UMATI. Most programs, however, began in the early 1990s. By December 1996, CBD programs were active in 22

Barbara Janowitz is director, Health Services Research Group, Family Health International (FHI), Research Triangle Park, NC, USA. Jane Chege is research associate, FRONTIERS Project, Population Council, Nairobi, Kenya. Andrew Thompson, formerly with FHI, is now administrator, Health Policy Unit, Organization for Economic Cooperation and Development, Paris. Naomi Rutenberg is research associate, HORIZONS Project, Population Council, Washington, DC. Rick Homan is senior research associate, Health Services Research Group, FHI. Funding and technical assistance were provided by the U.S. Agency for International Development (USAID) through the Population Council Africa Operations Research and Technical Assistance Project II and the FRONTIERS Project. The authors acknowledge the support of the Tanzania Ministry of Health's Family Planning Unit, UMATI and the Seventh-Day Adventist Community-Based Distribution Program. The research on which this article is based was made possible through support provided by (USAID) under contract CCP-3030-C-00-3008-00 and cooperative agreement HRN-A-00-98-00012. The opinions expressed herein do not necessarily reflect the views of USAID. 
of the 104 districts that make up Tanzania and Zanzibar Island. Our analysis examines the three largest programs, which use different schemes for remunerating CBD agents and spend varying amounts on training and on supervision: UMATI, the Tanzania Ministry of Health's Family Planning Unit (FPU) and the Seventh-Day Adventist (SDA) Community-Based Distribution Program (Table 1).

Agents in all these programs provide family planning services to women in their homes. They recruit new clients; supply and resupply pills, condoms and spermicides; and refer women who request clinical methods to appropriate providers. Also, UMATI and FPU agents provide maternal and child health referral services, while SDA agents provide information and referral services for both sexually transmitted diseases and maternal and child health. UMATI has two CBD approaches: One is part of an integrated project, which provides other services, such as income-generating activities and parasite control; the other is freestanding and provides only family planning services.

Each program uses a different strategy to remunerate its CBD agents. FPU enlists part-time volunteers, who are given a bicycle allow ance and in-kind contributions (e.g., bicycles, bags and metal boxes). UMATI also uses part-time volunteers, who are provided with in-kind payments (e.g., uniforms, bags, metal boxes and umbrellas) and equipment to share for income-generating activities (e.g., a boat, tractors and sewing machines). SDA employs full-time agents, who are given a salary and in-kind contributions (e.g., uniforms, bags, metal boxes and umbrellas). Further details about the programs have been published elsewhere. ${ }^{3}$ In this article, we analyze the impact of variations in how programs allocate their spending among staff compensation and training programs for community-based agents.

\section{Data and Methods \\ Variables}

- Costs. We have included the costs associated with remuneration of agents and their supervisors, and with training programs. While it seems obvious that the amounts spent on training and supervision affect agents' performance, it is not as obvious that the amount spent on remuneration has an indirect effect on programs' productivity. (Although remuneration policies also have an indirect effect on the productivity of resources used to provide administrative services, we exclude administrative costs of the organizations' home offices, because our

\begin{tabular}{|c|c|c|c|}
\hline Characteristic & Family Planning Unit (FPU) & UMATI & Seventh-Day Adventist (SDA) \\
\hline Sector & Public & $\begin{array}{l}\text { Nongovernmental } \\
\text { organization }\end{array}$ & $\begin{array}{l}\text { Church-based nongov- } \\
\text { ernmental organization }\end{array}$ \\
\hline Location & Rural, urban & Rural & Urban \\
\hline No. of agents (1996) & 663 & 683 & 189 \\
\hline Coverage & $\begin{array}{l}5 \text { regions, } 1 \text { urban } \\
\text { district, } 9 \text { rural districts }\end{array}$ & 5 regions, 6 districts & 5 regions, 6 districts \\
\hline CBD status & Volunteer & Volunteer & Salaried \\
\hline Remuneration & Incentives, allowance & $\begin{array}{l}\text { Incentives, income- } \\
\text { generating activities }\end{array}$ & $\begin{array}{l}\text { Monthly salary, } \\
\text { incentives }\end{array}$ \\
\hline Agents' gender & Male and female & Male and female & Almost all female \\
\hline Services & $\begin{array}{l}\text { Family planning, maternal } \\
\text { and child health }\end{array}$ & $\begin{array}{l}\text { Family planning, maternal } \\
\text { and child health, primary } \\
\text { health care }\end{array}$ & $\begin{array}{l}\text { Family planning, } \\
\text { maternal and child } \\
\text { health, sexually } \\
\text { transmitted diseases }\end{array}$ \\
\hline Supervision & Part-time; salaried staff & Part-time; CBD agents & Full-time; salaried staff \\
\hline $\begin{array}{l}\text { Ratio of agents } \\
\text { to supervisors (1996) }\end{array}$ & $6.4: 1^{*}$ & $10: 1$ & $16: 1$ \\
\hline Agent training & Initial, refresher & Initial, refresher & Initial, refresher \\
\hline Supervisor training & Initial, refresher & Initial only & Initial only \\
\hline
\end{tabular}

*Based on the number of full-time-equivalent supervisors in 1998.

focus is on resources that are directly linked to the improvement of agents' performance.)

The salaries of staff who supervise agents and, if appropriate, of higher-level supervisors are included because supervisors' compensation may increase agents' productivity if higher-paid supervisors do a better job helping agents improve performance. Agent compensation also has an indirect effect on the productivity of supervision. If, for example, the ratio of agents to supervisors is the same for all programs, regardless of agent compensation, while output is positively correlated with payments to agents, then the salary cost of supervisors per unit of output produced will be lowest in programs in which agents are paid the most.

Larger amounts spent on both training and retraining agents and supervisors should increase the productivity of both types of workers. Remuneration also has an indirect effect on the productivity of training. Theoretically, lower-paid agents are more likely to seek other employment, while higher-paid agents are more content to stay in the program working as agents. Therefore, the costs of training are spread over a shorter period for lower-paid than for higher-paid agents. Furthermore, if agents' output is greater when they are paid more, training and retraining costs will be divided by a larger output for higher-paid agents than for lower-paid agents, even if agents are employed for the same length of time.
It is difficult to determine the impact of remuneration on agent retention rates. $\mathrm{Al}$ though retention rates are very high, ${ }^{4}$ in programs in which agents are not salaried, workers may let their performance decline without resigning. Unfortunately, no information exists on how agent performance changes over time. Thus, our consideration of training costs does not adjust for changes in work performance over time, and the period over which training costs are annualized does not vary by program.

-Output. The average number of visits per CBD agent in some given period of time is the optimum output variable. The reason for this is that higher remuneration presumably encourages workers to spend more hours on the job and to produce more visits (i.e., to make contact with a greater number of potential clients), irrespective of other aspects of the job environment, including the demand for services and other program policies that affect whether contraceptives are provided or referrals are made during a visit.

Of course, CBD agents make many types of visits: In some, they provide methods; in others, they make referrals; and in still others, they attempt to motivate women to accept family planning services. The last category includes contacts in which women accept methods, as well as those in which they do not. The goal of any program is to increase contacts in which new acceptors are recruited, continuing users are resupplied or a referral is made that leads to a clinic 


\begin{tabular}{|c|c|c|}
\hline Program & $\begin{array}{l}\text { Immediate } \\
\text { supervisors }\end{array}$ & $\begin{array}{l}\text { Upper-level } \\
\text { supervisors }\end{array}$ \\
\hline FPU & 40 & 10 \\
\hline UMATI & na & 100 \\
\hline SDA & 90 & 50 \\
\hline
\end{tabular}

Note: na=not applicable, because immediate supervisors are specially trained agents, and for purposes of our analysis, we have treated them as agents

visit. Whether visits prove "successful" is therefore affected by both the worker's effort and the potential client's interest, and thus by demand factors that are unlikely to be related to workers' remuneration.

However, only one of the three programs (SDA) had information on total visits made by agents. Consequently, we were forced to use a less-satisfactory index of work performance, based on the number of visits in which a client was provided with contraceptives or was referred to a clinic for family planning services. (Referrals for other services were excluded from the analysis.) This measure may be affected by demand-side factors; thus, the impact of remuneration on work performance may be somewhat obscured. However, other analyses show that agents' performance is similar regardless of an area's prevalence, so the role of demand in affecting agent performance may be small. ${ }^{5}$

The average number of visits made by agents varies by gender, and the programs vary in their mix of male and female agents. We therefore adjusted the output variable to control for this difference: On average, female agents make $8.2 \%$ more visits than male workers. ${ }^{6}$ Thus, under the assumption that all agents were female (as in SDA) and that differences in productivity according to gender were the same for each program, we inflated the number of visits per agent in the FPU and UMATI programs (where agents are both male and female) by $8.2 \%$.

While it might seem appropriate to use couple-years of protection as the measure of output, this turns out to be a poor choice

\footnotetext{
*To annualize the cost of in-kind contributions, we used the following approach. First, we established the replacement cost of each item. Second, we estimated the useful life of each item, on the basis of interviews with program managers. Books, bags, metal boxes and uniforms were estimated to last two years; bicycles, five years; and heavy equipment and boats, seven years. Next, we determined what the program could have earned if it had invested the funds used to purchase the item, or the "opportunity cost of capital." We estimated that funds, conservatively invested, would have earned 5\% per annum.
}

because it is affected by supply factors that are independent of remuneration. These include variations by program in the number of oral contraceptives and condoms distributed during an average visit and in the method mix. A program that distributes more of any method per visit may produce more couple-years of protection and therefore may appear to be more costeffective, but the reasons are unrelated to remuneration. Another supply issue concerns method mix. SDA provides mainly pills; in the other programs, the mix is more evenly distributed between pills and condoms. One reason for this difference may be that the ratio of male to female agents varies; females tend to provide more pills than males, while both provide about the same number of condoms. ${ }^{7}$

\section{Data Collection}

We obtained data on costs from program managers and financial records for 1995 and 1996 for UMATI and SDA, and for 1995 only for FPU. Costs were divided by the number of agents working in each year to calculate the annual cost per agent.

SDA was the only program that paid a salary to its agents. FPU provided a small allowance to some agents for bicycle maintenance. The three programs made different types of in-kind contributions to their agents. Each contribution can be classified as a capital good. To make costs comparable with those for items that are used up in a year, we annualized the cost of capital goods or spread it over the useful life of the item. ${ }^{*}$ The annualized cost was divided by the number of agents in each program to determine the value of in-kind contributions per agent. ${ }^{+}$

Each CBD program has two types of supervisors. Immediate supervisors are responsible for regularly checking on agents, while upper-level supervisors generally are responsible for managing immediate supervisors. Payments to supervisors include salaries and benefits, travel allowances and transportation costs for time spent on field visits. In the UMATI program, selected CBD agents worked as

IIn FPU and SDA, all CBD agents typically received the same in-kind contributions. However, UMATI gave its agents different items, depending on the district in which they worked. Therefore, the annual cost per agent for this program was weighted according to the number of agents in each district.

‡Vehicle operating costs include the cost of fuel, maintenance, repair, insurance and licenses. Typically, use of the vehicles was shared among CBD and other activities. Therefore, vehicle operating costs were allocated to the CBD program using estimates from program managers of the proportion of time that vehicles were used for CBD immediate supervisors. To facilitate the analysis, we treated all supervision costs incurred by these agents (including travel costs and the cost to train them to be supervisors) as payments to agents.

Information was obtained from program managers on the salaries and benefits paid to immediate and upper-level CBD supervisors. Many of the supervisors have additional duties that are not related to CBD activities, and it is therefore not appropriate to charge their total remuneration to the CBD program. To address this problem, we interviewed supervisors in two districts in each program and asked them to estimate the proportion of time they spend per week on CBD activities. We used this information (shown in Table 2) to allocate a proportion of the salaries and benefits of supervisors to the CBD program. Remuneration attributed to CBD supervision was then divided by the number of agents to determine the cost per agent of salaries and benefits.

In each program, the upper-level CBD supervisors are provided with vehicles and travel allowances for transportation to meet immediate supervisors. The programs do not support transportation used by immediate CBD supervisors. We also measured per diem expenses and vehicle operating costs associated with supervisor transportation. $\ddagger$ The sum of these costs was divided by the number of CBD agents to calculate the supervisor transportation cost per agent.

Information on annual training costs and the number of agents and supervisors trained was obtained from program expenditure accounts between 1993 and 1996. Training costs include those for travel and per diem for both trainers and trainees, the costs of supplies and any rental fees. The costs of the training seminars were annualized. $\$$ The cost of training immediate supervisors was divided by the number of agents to determine the supervisor training cost per agent. All programs use either personnel from FPU or their own staff to carry out

(continued on page 193)

supervision. The cost of the vehicles was not measured because of lack of information. The labor cost of drivers also was not included because of lack of information.

$\S$ The costs of refresher training sessions were annualized over a two-year period, as refresher training is conducted every two years. It was more difficult to determine the useful life of the initial training sessions, which should equal the number of years that agents and immediate supervisors are expected to work in the program. We annualized costs over a 10-year period. Our analysis shows that the rank order of cost per visit is not affected by changes in this assumption (source: reference 3 ). 
Community-Based...

(continued from page 160)

training sessions, but the costs of these staff are not available and are excluded from the analysis.

Data on the output variable - agents' visits-were obtained from the headquarters of each program. The annual number of visits produced by each program was divided by the number of active agents in the same period to calculate the average annual number of visits per agent. (The annual number of CBD agents was adjusted to account for agents who did not work for the entire year-agents who dropped out or who received their initial training during, and not at the beginning of, the year.)

\section{Results}

\section{Cost per Agent}

SDA agents receive compensation totaling US $\$ 398$ - about nine times the total received by UMATI workers and 12 times that received by FPU agents (Table 3 ).

Total per-agent payments to supervisors also are higher in SDA (\$239) than in FPU (\$214) or UMATI (\$33*). However, while supervisors' salaries are higher in SDA than in FPU (not shown), the ratio of agents to immediate supervisors is also higher in SDA; as a result, supervisor costs are spread over a greater number of agents, and supervisors' salaries and benefits, calculated per agent, are $27 \%$ lower in SDA than in FPU. Average travel costs per supervisor are highest in SDA (\$75, compared with \$5-11 in the other programs), reflecting that area managers travel frequently because they are responsible for a large number of agents.

Training costs per agent vary greatly; total costs at FPU (\$312) are substantially higher than those at the other programs

Table 3. Average annual cost per CBD agent, by program, according to type of cost, 1995-1996

\begin{tabular}{lccr}
\hline Type of cost & FPU* & UMATI & \multicolumn{1}{c}{ SDA } \\
\hline Total cost per agent & $\mathbf{\$ 5 5 8 . 2 0}$ & $\mathbf{\$ 1 5 5 . 4 9}$ & $\mathbf{\$ 7 0 0 . 7 4}$ \\
& & & \\
Payment to CBD agents & $\mathbf{3 3 . 0 2}$ & $\mathbf{4 4 . 4 0}$ & $\mathbf{3 9 8 . 1 6}$ \\
Salaries and benefits & $\mathrm{na}$ & $\mathrm{na}$ & 341.04 \\
In-kind payments & 33.02 & 44.40 & 57.13 \\
Payments to supervisors & $\mathbf{2 1 3 . 5 5}$ & $\mathbf{3 2 . 8 0}$ & $\mathbf{2 3 8 . 9 8}$ \\
Salaries and benefits & 208.20 & 21.85 & 163.74 \\
Travel costs & 5.35 & 10.95 & 75.24 \\
& & & \\
Training costs & $\mathbf{3 1 1 . 6 2}$ & $\mathbf{7 8 . 3 0}$ & $\mathbf{6 3 . 5 9}$ \\
Agent & 231.80 & 78.30 & 55.21 \\
Immediate supervisor $\ddagger$ & 79.82 & na & 8.39 \\
\hline
\end{tabular}

*1995 only. †Annualized over 10 years for initial training and over two years for refresher training. $\ddagger$ Costs of training upper-level supervisors are excluded. Notes: Costs are shown in U.S. dollars. For UMATI and SDA, costs are based on an average of midyear exchange rates for 1995 and 1996 (US $\$ 1=561.5$ Tanzanian shillings); for FPU, costs are based on the 1995 midyear exchange rate (US $\$ 1=528$ Tanzanian shillings). na=not applicable, because immediate supervisors are specially trained agents, and for purposes of our analysis, we have treated them as agents. Dollar amounts may not add to totals because of rounding.
(\$64-78). It is difficult to explain why these costs vary so much. The main difference is in the costs of refresher training (not shown), although policies regarding refresher training are the same in all three programs. Some combination of the following factors may also contribute to the variation: FPU may incur higher costs for enues, travel and per diem, and may class sizes, than the other proining costs of supervisors per agent are far higher for FPU (\$80) than for SDA (\$8). FPU supervisors spend only of their time supervising agents; trained for FPU to have a training coverage rate similar to that in other programs. , only FPU provides refresher training fupervisors. UMATI supervisors are selected from among agents, so there no additional training costs.

costs per agent are far lower in (Table 3). In fact, the cost per agent in MATI (\$155) is only slightly more than of the cost per agent in FPU (\$558), 政 er-agent costs at SDA (\$701) are even though at FPU, tion is more than 10 times that of FPU. Thus, a program that makes only small payments to its agents will not necessarily have the lowest total cost per agent, and a program that spends a lot on agent compensation may not have commensurately higher costs per agent.

\section{Output per Agent}

Not unexpectedly, the annual number of visits per agent is by far highest (425) in the SDA program, in which agents are full-time, salaried workers (Table 4). FPU and UMATI agents make 105 and 132 visits per year, respectively. (These numbers rise to 113 and 143 , respectively, when adjusted for gender differences.) In addition to remuneration policies, location may explain some of the difference in the number of visits made by SDA workers and others, since SDA agents work in urban areas, while most agents in the other two programs work in rural areas. ${ }^{\dagger}$
Table 4. Average annual numbers of total visits, CBD agents and visits per CBD agent, by program, 1995-1996

\begin{tabular}{lll|ll}
\hline Program & $\begin{array}{l}\text { Total } \\
\text { visits* }\end{array}$ & Agents & \multicolumn{2}{|l}{ Visits per agent } \\
\cline { 4 - 5 } & & Actual & Adjusted $†$ \\
\hline FPU $\ddagger$ & 41,495 & 396 & 105 & 113 \\
UMATI & 65,143 & 494 & 132 & 143 \\
SDA & 67,529 & 159 & 425 & 425
\end{tabular}

*Includes only visits in which a method is provided or a referral for family planning is made. †Adjusted assuming all CBD agents are female. $¥ 1995$ only.

\section{Effects of Remuneration Policies}

Costs per visit are lowest in UMATI, somewhat higher in SDA and far higher in FPU (Figure 1, page 194). While SDA has the highest number of visits per agent, UMATI has far lower costs per agent, so it also has the most favorable cost-per-visit ratio. If only payments to agents are considered, then FPU has the lowest cost per visit. However, when indirect effects are taken into consideration, UMATI's cost per visit is the lowest. $\ddagger$

While it seems intuitive that higher agent compensation would lead to higher costs per visit, this often turns out not to be true, as shown by the results of simulations assuming varying levels of spending on training and supervision. When the sum of training and supervision costs is high (as in SDA), an increase in compensation to agents leads to a reduc-

*UMATI salaries for supervisors include only those for higher-level supervisors, since immediate supervisors receive only the same in-kind compensation as agents do and their compensation is included in the line item for agent compensation. If the salaries of the immediate supervisors are included with those of the supervisors, the cost per agent increases to $\$ 172.62$.

tWe compared areas selected from the Tanzania Demographic and Health Survey that were located in regions with similar contraceptive prevalence levels, although the districts for which the comparisons were made may have different levels of contraceptive prevalence, unmet need and population density. The comparisons were also for districts in which programs were operating for at least two years. The results for pairwise comparisons show that the average number of visits in urban areas was far higher for SDA agents than for agents from FPU or from the Ministry of Health in Zanzibar. Also, the performance of urban agents in the FPU program is not superior to that of rural agents. In addition, the average number of visits for rural agents is higher in the UMATI than in the FPU program (source: reference 3 ).

‡We also compared the costs per couple-year of protection for the three programs. We found that these costs were lowest in the SDA program (\$5.69), slightly higher in UMATI (\$6.23) and highest in FPU (\$37.88). On average, SDA agents are more likely to provide pills than condoms, and they provide more pills in a visit than do agents in the other two programs. SDA's advantage by this measure is particularly surprising because its agents make a higher proportion of visits in which referrals are made and therefore contraceptives are not provided. 


\begin{tabular}{|c|c|c|c|}
\hline \multirow{2}{*}{$\begin{array}{l}\text { Cost of supervision } \\
\text { and training }\end{array}$} & \multicolumn{3}{|c|}{ Level of remuneration and visits per agent } \\
\hline & Low (FPU) & Medium (UMATI) & High (SDA) \\
\hline High (SDA) & $\$ 2.97$ & $\$ 2.43$ & $\$ 1.65$ \\
\hline Low(UMATI) & 1.28 & 1.09 & 1.20 \\
\hline
\end{tabular}

tion in costs per visit (Table 5).* This occurs because indirect effects dominate; that is, the larger number of visits made by more highly compensated agents more than outweighs any increase in costs that arises because agents are more highly paid. By contrast, when training and supervision costs are low (as in UMATI), the cost per visit varies little by difference in compensation of agents.

One possible explanation for these findings is that agents respond to increases in compensation by working longer hours and making additional visits, and that training and supervision may affect the quality of visits without increasing their quantity. This explanation seems reasonable, given that the number of visits is largest in SDA, the organization with the highest compensation per agent, and smallest in FPU, the organization that has the lowest compensation per agent.

The important conclusion from this part of the analysis is that the impact of agent remuneration on cost per visit cannot be evaluated by focusing on compensation alone. When the effects of supervision and training costs are taken into consideration, UMATI and SDA have lower costs per

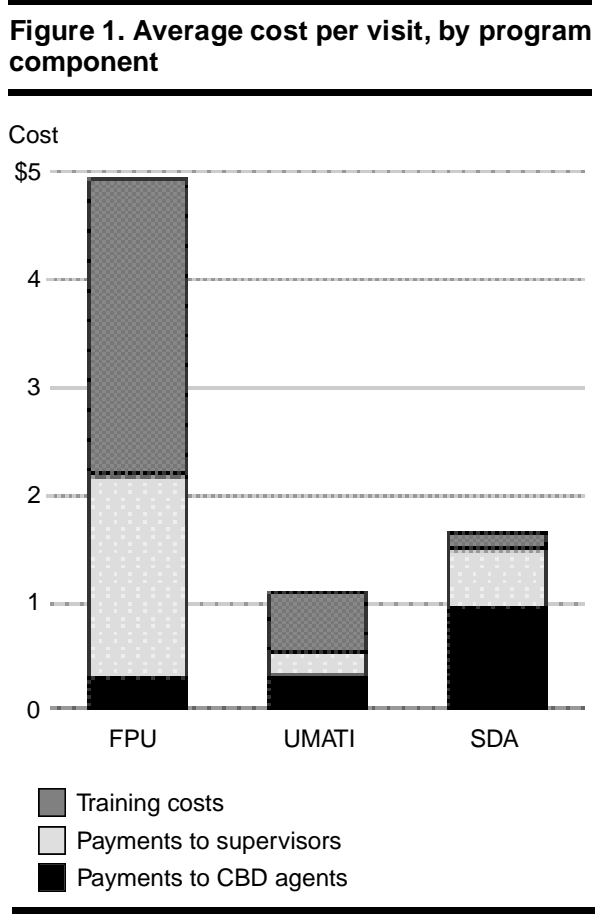

visit than FPU, because they have either low costs for these program functions (UMATI) or a high number of visits over which they divide these costs (SDA). In the latter case, the high compensation of agents in SDA likely results in a large number of visits per agent. When training and supervision costs are high, as they are in both SDA and FPU, a large number of visits is necessary to generate a reasonably low cost per visit. This is the case for SDA but not FPU.SDA's higher compensation is more than offset by its higher number of visits, resulting in a much lower cost per visit at SDA than at FPU.

\section{Conclusions}

When only payments for agents are considered, FPU has the lowest cost per visit. However, when other costs are taken into account, FPU turns out to have the highest cost per visit. This is because low compensation results in a low number of visits; the indirect effect is high costs per visit, when the costs of supervision and training are taken into consideration.

In the three programs we analyzed, remuneration was positively associated with the number of agent visits. Although agents in both UMATI and FPU receive only inkind compensation, the higher payments in UMATI are associated with a greater number of visits per agent than occur in FPU. InSDA, the program in which agents are paid a salary, visits are far more numerous. However, we were unable to control for factors that affect job performance over and above those analyzed in this article. Program factors that are hard to measure, such as the loyalty of workers and their willingness to work long hours with small rewards, simply cannot be captured in this kind of analysis. Moreover, the greater amounts spent on training and supervision in SDA and FPU may have had a positive impact on both the number of visits and their quality. Previous research, however, indicates that reducing supervisory visits may not affect agent performance. ${ }^{8}$ This is because supervisors may use their visits to collect revenue and resupply agents rather than to provide them with motivation to improve their output. However, research from Mali suggests that refresher training may have a positive impact on the performance of CBD agents. ${ }^{9}$

The UMATI program has the lowest cost per visit because it has consistent policies regarding remuneration, training and supervision. Remuneration is low because agents are volunteers and select their own hours of work. At the same time, in designing its supervision and training strategies, the organization either explicitly or implicitly recognizes that its agents do not work full-time. Supervision and training strategies are low-cost and are consistent with a program that does not have very high output per worker.

By contrast, FPU pays its agents little, and like UMATI workers, they select how much time they wish to spend working. However, FPU's high costs of supervision and training seem inconsistent with a program that employs workers who receive little compensation. SDA has high payments to agents, and spends about the same per agent on supervision and training as does FPU. However, it makes more sense for SDA to invest in training and supervision, as its agents produce more output and work for a longer time.

Costs vary in these programs, and much of the variation may be explained by policies not associated with remuneration; this is apparent in that the two programs that pay agents in-kind have very different cost structures. This finding suggests that a broad focus should be taken in examining costs of CBD programs. While it is important to examine the impact of remuneration, such a focus may be too narrow. For example, programs may spend little on remuneration but large amounts on training or supervision. The challenge is not simply how to compensate agents so as to get the most output per dollar spent on compensation. The larger concern is how to allocate funds for the CBD program among the various strategies for improving performance: agent compensation, supervision, and agent and supervisor training. Some programs that spend little on compensation might improve performance by spending more on compensation but less on training or supervision. For example, FPU could consider using more of its budget to compensate agents while reducing other costs.

Our results have important implications for the financial sustainability of CBD programs. In preparing for declines in donor funding, programs need to take a broader approach than simply slashing salaries

*We use supervision and training costs for SDA even though these costs are higher for FPU. This is because there is wide variation in the annual costs per agent trained in FPU but not in SDA (or in UMATI). Thus, even if reported costs for training are too high for FPU, the implications of changing remuneration are the same, assuming the somewhat lower training and supervision costs of SDA. 
or payments to agents. The full budget should be examined so as to determine how the program could best survive with less funding from donors.

\section{References}

1. Phillips JF, Greene WL and Jackson EF, Lessons from Community-Based Distribution of Family Planning in Africa, Policy Research Division Working Papers, New York: Population Council, 1999, No. 121.

2. Ibid.

3. Chege J et al., Factors Affecting the Outputs and Costs of Community-Based Distribution of Family Planning Services in Tanzania, New York: Population Council, 1998.

4. Ibid.

5. Ibid.

6. Ibid.

7. Ibid.

8. Foreit JR and Foreit KG, Quarterly versus monthly supervision of CBD family planning programs, Studies in Family Planning, 1984, 15(3):112-120.

9. Katz KR et al., Increasing access to family planning in rural Mali through community-based distribution, International Family Planning Perspectives, 1998, 24(3): 104-110.

\section{Resumen}

Contexto: Los fondos de los donantes parecen ser insuficientes para apoyar la creciente demanda de servicios que prestan los programas de distribución comunitaria de anticonceptivos (DCA). Una solución a este problema podría ser reducir la remuneración de los agentes de estos programas, aunque este enfoque podría reducir su productividad. Asimismo, los programas deben considerar reducir otros costos, incluidos los de supervisión y capacitación. Métodos: Se calculó el costo de cada visita que hace una trabajadora DCA-incluidos los costos relacionados con el pago a las trabajadoras y supervisores y los gastos por concepto de capacitación-correspondientes a tres programas DCA en Tanzania. La medida de productividad se basó en las visitas en que se distribuyeron anticonceptivos o se refirió a las interesadas a servicios de planificación familiar. Se utilizaron técnicas de simulación para examinar el impacto del cambio de remuneración de las trabajadoras con respecto a los costos por visita, asumiéndose diferentes niveles de gastos de capacitación y supervisión.

Resultados: El programa que les pagó a las trabajadoras la mayor compensación anual (US \$398) también presentó el nivel más elevado de costo por agente (\$701), aunque también presentó el más elevado número de visitas ofrecidas hechas por la trabajadora (425). El programa que presentó el nivel de compensación más bajo por agente (\$33) también presentaba elevados costos por agente (\$558), porque sus otros costos eran elevados y sus agentes producian pocas visitas (105). Mediante esta técnica de simulación se observó que un au- mento del costo de la remuneración de una trabajadora reduce el costo de cada visita, porque aumenta el número de las mismas, y de esa manera se distribuyen los costos por concepto de supervisión y capacitación sobre un número mayor de visitas.

Conclusiones: El desafío que enfrentan los programas DCA que procuran reducir sus costos, es determinar cuáles son los gastos que se pueden reducir, para que minimice una reducción del número de visitas. Por ejemplo, los programas que gastan poco en sueldos podrían mejorar su rendimiento si aumentan éstos, y reducen los gastos de supervisión y capacitación.

\section{Résumé}

Contexte: Les fonds des donateurs pourraient être inaptes à soutenir la demande croissante de prestations assurées par les programmes de distribution communautaire (DC). Une solution serait de réduire la rémunération des agents DC, mais cette approche risquerait de réduire aussi leur productivité. Il convient d'envisager aussi la réduction d'autres coûts, notamment ceux de l'encadrement et de la formation.

Méthodes: Le coût par visite d'agent—coûts de rémunération des agents et cadres et coûts de formation inclus - a été calculé pour trois programmes DC tanzaniens. La mesure de sortie était les visites conclues par la fourniture de contraceptifs ou par un renvoi aux services de planning familial. L'incidence de variations de la rémunération des agents sur les coûts par visite, compte tenu de différents niveaux de dépenses de formation et d'encadrement, a été examinée par simulation.

Résultats: Le programme qui offrait la plus haute rémunération annuelle à ses agents (US \$398) était associé aux coûts les plus élevés par agent (US \$701), mais présentait aussi le plus grand nombre de visites par agent (425). Le programme le moins rémunérateur (compensation annuelle de US \$33) était également assorti de coûts élevés par agent (US \$558), en raison de ses autres coûts également élevés et du faible nombre de visites assurées par ses agents (105). Les simulations révèlent que l'augmentation de la rémunération des agents réduit les coûts par visite, sous l'effet $d u$ nombre accru des visites d'agent, répartissant ainsi les coûts d'encadrement et de formation sur un plus grand nombre de visites.

Conclusions: Le défi à relever par les programmes DC désireux de réduire leurs coûts sera d'identifier les composants de leurs coûts dont la réduction s'accompagnera d'une réduction minimale du nombre de visites. Par exemple, les programmes dont les coûts de rémunération sont faibles pourraient améliorer leurs résultats en accroissant la rémunération de leurs agents mais en réduisant ainsi leurs coûts de formation et d'encadrement. 